\title{
Assessment of a Website Aimed at Providing Information on Mental Health to Secondary School Students in Cantho City, Vietnam
}

Dat Tan Nguyen ( $\square$ ntdat@ctump.edu.vn )

Can Tho University of Medicine and Pharmacy https://orcid.org/0000-0002-6192-603X

Tam Thi Pham

Can Tho University of Medicine and Pharmacy

E. Pamela Wright

Guelph International Health Consulting

Joske Bunders

Vrije Universiteit Amsterdam

\section{Research Article}

Keywords: Website, Internet, mental health, students, Cantho, Vietnam

Posted Date: May 17th, 2021

DOl: https://doi.org/10.21203/rs.3.rs-509703/v1

License: (c) (i) This work is licensed under a Creative Commons Attribution 4.0 International License.

Read Full License 


\section{Abstract}

Background: The stigmatization of mental health problems is a primary barrier for young people to approach mental health services when they suspect they might have a problem. Instead it is becoming common, especially for youth, to look for information on the Internet. This study explored the responses of secondary school students in Cantho city to the suckhoetre.vn website, which aimed to provide information on health and mental health, and to assess its potential relevance, appeal, accessibility, usefulness, and sustainability.

Methods. A cross-sectional study included 643 secondary school students in Cantho city selected by cluster sampling. Students were introduced to the website; after two weeks they were invited to evaluate it using an anonymous questionnaire. The Chi-squared test was used to assess the significance of differences in the distribution of selected sociodemographic characteristics.

Results. Most (98.6\%) of the students visited the website in the two-week period, $74 \%$ once or twice a week, the others more often, up to once a day. Their activities included reading information (85.8\%), seeking help (17.7\%), sharing information (15.5\%), giving advice to others $(11.0 \%)$, and chatting or giving comments (9.8\%). Most students rated the website very highly in terms of appeal, relevance, accessibility, and usefulness, and wanted to have access to the website in the future. These findings are positive signals to pursue the application of a website on mental health for secondary school students as a contribution to better mental health for adolescents in Cantho city and elsewhere.

Conclusion: A website designed to provide information to secondary school students appeared to be an effective way to provide access to information on the sensitive topic of mental health. The website should be maintained and introduced more widely to students, teachers and parents, with a continuous evaluation of its effectiveness.

\section{Background}

Despite the high risk of mental disorders in adolescence, many young people are not receiving appropriate support and guidance from mental health professionals and the community (including family and school); they lack access to health care and education facilities (World Health Organization, 2019b). In recent years it has become commonplace for individuals to seek health information on the Internet. Several websites on mental health in different countries, such as KidsHealth.org, youthbeyondb/ue.com, and tamlydoisong.wordpress.com, appear to play a significant role in improving understanding of mental health and reducing symptoms of depression (Boydell et al., 2014; Duplaga \& Dzida, 2013; Moock, 2014). Most adolescents in urban areas in high-income countries have access to and make use of online information on mental health, especially for disorders regarded as behavioral problems. That young people tend to turn to the Internet suggests that they are willing to seek help, and they might be prepared to cooperate with others having similar mental health problems and contribute to forming peer support networks. With the spread of the Internet, it has been recognized that it can contribute to increasing the 
accessibility of health care (Moock, 2014). There have been few reports, however, on combining the Internet with positive psychology for health promotion and reduction of mental health symptoms (Mitchell, Vella-Brodrick, \& Klein, 2010).

Vietnam is one of the nations with the most rapidly growing use of the Internet, with a greater development than most other countries in the region. It is reported that approximately 50 million Vietnamese, or half of the population, were connected to the Internet in 2017 and Vietnam's penetration rate $(54 \%)$ was higher than the world average (46.5\%) (EU-Vietnam Business Network, 2018). Two thirds of the Internet users accessed it every day, spending on average about 2 hours 20 minutes on weekdays, less at weekends. Popular places to access the Internet were at home (78\%), at work (31\%) and in Internet shops or cafés (25\%) (Cimigo, 2011).

Previous studies in Vietnam showed that mental health problems in relation to young people should be a major concern for health authorities, schools, communities, and families (Dat Tan Nguyen, 2009; T. H. Nguyen, 2006; Tran, 2007). Of particular relevance to this study were the high levels of depression, anxiety, and suicidal ideation among secondary school students in Cantho city (D. T. Nguyen, C. Dedding, T. T. Pham, P. Wright, \& J. Bunders, 2013). However, although the primary health care system in Vietnam is quite strong, primary mental health care - especially for mental health problems in children - is nonexistent. Despite some progress, the service environment and response to mental health problems in Vietnam remain largely inadequate. The situation is even worse outside the major cities in remote provinces, which lack mental health services and cannot prevent or treat children's mental health disorders (UNICEF, 2018). Stigma related to mental health is highly prevalent in Vietnam, and is recognized as one of the main factors hindering youth from approaching mental health services (van der Ham, Wright, Van, Doan, \& Broerse, 2011).

In our previous studies in Vietnam, relevant stakeholders including students, teachers and school health officers had suggested that a web-based information resource on psychology and mental health could be helpful for students (Dat Tan Nguyen, Christine Dedding, Tam Thi Pham, \& Joske Bunders, 2013; Dat Tan Nguyen, Christine Dedding, Tam Thi Pham, Pamela Wright, \& Joske Bunders, 2013; Dat T. Nguyen, Dedding, Wright, Pham, \& Bunders, 2019; Dat Tan Nguyen, Wright, Pham, \& Bunders, 2020). In addition, most of the students reported that they would share their private problems and seek help from a website, if one were available.

For these reasons, it is possible that students and adolescents in Vietnam could benefit from access to information about mental health through a website, where they can remain anonymous. Since there was no existing website providing specifically mental health information aimed at that age group, we designed one, with consideration for the characteristics of teenagers and adolescents. The suckhoetre.vn (youth health) website has three main sections, providing students with information on health, on healthrelated skills, and a health check-up. The main contents were designed based on key topics in general health care, sexual orientation, love and relationships, drug and game addictions, reproductive health, nutrition, and skills to scope with stress in life, as mentioned by students, teachers and parents in 
previous studies (Dat Tan Nguyen, Dedding, Pham, \& Bunders, 2013; Dat Tan Nguyen, Dedding, Pham, Wright, et al., 2013; Dat T. Nguyen et al., 2019; Dat Tan Nguyen et al., 2020). Information in Vietnamese posted on the suckhoetre.vn was translated and cited from information in both national and international websites, such as kidshealth.org website (The Nemours Foundation, 2020), Mai Huong Daycare Psychiatric Hospital website (Bệnh Viện Tâm Thần Ban Ngày Mai Hương, 2020), and Depression website (Bệnh Lý Trầm Cảm, 2020). In addition, current health status screening was integrated in the website, including the General Health Questionnaire (Sanchez-Lopez Mdel \& Dresch, 2008; Zulkefly \& Baharudin, 2010), the CES-D (Radloff, 1977), the Rosenberg self-esteem scale (M. Rosenberg, 1965; Morris Rosenberg, 1989), and the Educational Stress Scale for adolescents (Thai et al., 2012). Information translated into Vietnamese was checked by the researchers for accuracy and by students of Can Tho University of Medicine and Pharmacy for accessibility to young readers. The design and interface of the website were shaped by the researchers in collaboration with students of Can Tho University of Medicine and Pharmacy. The first draft version was piloted with three school health officers and ten students for feedback, to complete the website. It was launched for public use in 2016, with the aim of meeting the needs of secondary school students for information on mental health and psychological wellbeing in Cantho city.

After the website was available, we recruited secondary school students to investigate whether they appreciated the features of the website, and whether it might be a way forward to recommend to education authorities as a tool to improve students' mental health. Until now, the website is still available for public use, but has not had regular updates on the information as it did during the study.

\section{Methods}

\section{Study design and population}

To assess the effectiveness of the website in providing information on mental health, a cross-sectional study was carried out with 643 secondary school students including 318 boys and 325 girls, mean age: 16.99 years. The students were recruited using random sampling in three stages. Firstly, three schools were selected, including the only specialized school in Cantho city and two of the 23 regular secondary schools, one in an urban and one in a rural district of the city. The regular schools had 61 classes of grades 10 to 12 with an average 35 students per class. Two classes from each grade from 10 to 12 were randomly selected by coding all classes in these grades with a number and using Excel software to select two numbers randomly per grade. The specialized secondary school had 26 classes of grades 10 to 12; three classes from these grades were randomly selected. All students in each selected class were invited to participate. The number of valid completed questionnaires was 643 , which is $95.4 \%$ of the 674 distributed; the other questionnaires were excluded because they were incomplete. Data collection took place in November 2016.

\section{Data collection}


The suckhoetre.vn website, its purpose, and the aims of this study were introduced to the students in the selected classes. The students were invited to use the website, then after two weeks, they were asked to complete the questionnaire anonymously.

The questionnaire consisted of five components asking the participants about: (1) demographic information on their age, sex, class, school, means of Internet connection; (2) their access situation (visited the site or not, visiting activities, number of visits during last seven days); (3) their evaluation of the usefulness, relevance, interest, appeal, and accessibility, using a 5- or 7-point Likert scale ranging from "extremely" to "not at all" with a neutral midpoint, and their willingness to maintain access to the website; and (4) whether they did or would introduce the suckhoetre.vn website to others. The questionnaire was composed and completed in Vietnamese. An English version is provided in the supplementary file S1.

These measurements were done for each item from the three main sections of the website: health, skills, and health check-up, to identify which information was most relevant to the students, and which information the students most liked or disliked.

In addition to the data obtained from the questionnaires, we consulted the website's own data after it had been up for one year, to find out whether it was still being used.

\section{Statistical analysis}

Data were entered into and analyzed by SPSS software 18.0. Data are presented as means \pm standard deviation (SD) and analyzed descriptively to determine the demographic characteristics of the study population. The Chi-squared test $(\chi 2)$ was used to assess the significance of differences in the distribution of selected sociodemographic characteristics. All tests were 2-tailed and a p-value of $<0.05$ was considered statistically significant.

\section{Results}

\section{Socio-demographic characteristics of the sample}

Completed questionnaires were submitted by 643 secondary school students, with a mean age of 16.99 years, ranging from 16 to 20 years. The numbers of boys and girls were close to equal. The number of students from the two regular schools was higher than from the one specialized school. The percentages of students from grades 10,11 and 12 were $35.9 \%, 31.1 \%$, and $32.8 \%$, respectively. 
Table 1

Socio-demographic characteristics of the sample

\begin{tabular}{|c|c|c|c|c|c|c|c|}
\hline \multirow[t]{2}{*}{ Characteristics } & \multicolumn{2}{|l|}{ Total } & \multicolumn{2}{|l|}{ Boys } & \multicolumn{2}{|l|}{ Girls } & \multirow[t]{2}{*}{$\mathbf{P}$} \\
\hline & $\mathrm{n}$ & $\%$ & $\mathbf{N}$ & $\%$ & $\mathbf{n}$ & $\%$ & \\
\hline Total & 643 & 100 & 318 & 49.5 & 325 & 50.5 & \\
\hline Age $($ mean $\pm S D)$ & \multicolumn{2}{|c|}{$16.99 \pm 0.86$} & \multicolumn{2}{|c|}{$17.03 \pm 0.89$} & \multicolumn{2}{|c|}{$16.96 \pm 0.83$} & $0.341^{\mathrm{a}}$ \\
\hline Age group & & & & & & & $0.042^{b}$ \\
\hline 16 & 228 & 35,5 & 114 & 35.85 & 114 & 35.08 & \\
\hline 17 & 203 & 31,6 & 87 & 27.36 & 116 & 35.69 & \\
\hline $18-20$ & 212 & 32,9 & 117 & 36.79 & 95 & 29.23 & \\
\hline Type of school & & & & & & & $0.208^{\mathrm{b}}$ \\
\hline Specialized & 211 & 32.8 & 99 & 31.1 & 112 & 34.5 & \\
\hline Regular & 432 & 67.2 & 219 & 68.9 & 213 & 65.5 & \\
\hline Grade & & & & & & & $0.027^{b}$ \\
\hline 10 & 231 & 35,9 & 116 & 36.5 & 115 & 35.4 & \\
\hline 11 & 201 & 31,3 & 85 & 26.7 & 116 & 35.7 & \\
\hline 12 & 211 & 32,8 & 117 & 36.8 & 94 & 28.9 & \\
\hline
\end{tabular}

${ }^{a}$ t-test was used to compare differences in mean of age according to sex.

${ }^{b} X^{2}$ was used to compare differences in age groups, types of school and grades according to sex.

Almost all of the students (99.2\%) had access to devices for an Internet connection. The mobile phone was the most popular way to access the Internet, used by nearly two thirds of the students. Nearly half used a laptop, about one third a computer and around one fifth used an iPad.

\section{Usage of the suckhoetre.vn website}

After receiving information about suckhoetre.vn, nearly all of the students visited the website within the first two weeks after its launch. Their main activity on the website was reading information, but $10-20 \%$ of students also used it for seeking help, sharing information, giving advice to others, and chatting or giving comments (Table 2).

Most of the activities were similar among the students. However, the percentage of students from regular shools seeking help was significantly higher than among students from the specialized schools. Sharing information on the website was more common among boys than among girls. 
Table 2

Main activities on suckhoetre.vn website within two weeks of its launch

\begin{tabular}{|c|c|c|c|c|c|c|c|}
\hline \multirow{3}{*}{$\begin{array}{l}\text { Reported } \\
\text { Activity }\end{array}$} & \multirow{3}{*}{$\begin{array}{l}\text { Total } \\
\%(n)\end{array}$} & \multicolumn{3}{|l|}{ Sex } & \multicolumn{3}{|l|}{ School } \\
\hline & & Male & Female & $\mathrm{p}^{\mathrm{a}}$ & Specialized & Regular & $\mathrm{p}^{\mathrm{a}}$ \\
\hline & & $\%(n)$ & $\%(n)$ & & $\%(n)$ & $\%(n)$ & \\
\hline Not visited yet & $1.4(9)$ & $1.6(5)$ & $1.2(4)$ & 0.487 & $1.9(4)$ & $1.2(5)$ & 0.487 \\
\hline Visited & $\begin{array}{l}98.6 \\
(634)\end{array}$ & $\begin{array}{l}98.4 \\
(313)\end{array}$ & $\begin{array}{l}98.8 \\
(321)\end{array}$ & & 98.1 (207) & $\begin{array}{l}98.8 \\
(427)\end{array}$ & \\
\hline $\begin{array}{l}\text { Read } \\
\text { information }\end{array}$ & $\begin{array}{l}85.8 \\
(544)\end{array}$ & $\begin{array}{l}84.0 \\
(263)\end{array}$ & $\begin{array}{l}87.5 \\
(281)\end{array}$ & 0.124 & $88.9(184)$ & $\begin{array}{l}84.3 \\
(360)\end{array}$ & 0.075 \\
\hline Search for help & $\begin{array}{l}17.7 \\
(112)\end{array}$ & $20.1(63)$ & $15.3(49)$ & 0.067 & $11.6(24)$ & $\begin{array}{l}20.6 \\
(88)\end{array}$ & $0.003 *$ \\
\hline $\begin{array}{l}\text { Share } \\
\text { information }\end{array}$ & $15.5(98)$ & $18.5(58)$ & $12.5(40)$ & $0.022^{*}$ & $15.0(31)$ & $\begin{array}{l}15.7 \\
(67)\end{array}$ & 0.457 \\
\hline Give advice & $11.0(70)$ & 12.1 (38) & $10.0(32)$ & 0.228 & $11.1(23)$ & $\begin{array}{l}11.0 \\
(47)\end{array}$ & 0.533 \\
\hline Chat/Comment & $9.8(62)$ & 10.5 (33) & $9.0(29)$ & 0.307 & $12.1(25)$ & $8.7(37)$ & 0.113 \\
\hline Other & $1.4(9)$ & $1.3(4)$ & $1.6(5)$ & 0.516 & $2.4(5)$ & $0.9(4)$ & 0.133 \\
\hline
\end{tabular}

${ }^{a} X^{2}$ was used to compare differences in accessing and activities on the website according to sex and types of school.

$* p<0.05$

In the week preceding their completing the questionnaire, more than $75 \%$ of the students had visited the website once or twice, while fewer than $10 \%$ had visited it more often than that. No significant differences were noted between boys and girls or between specialized and regular schools in the frequency of visiting the website in that week $(p>0.05)$.

\section{Students' evaluation of usefulness, relevance, interest, appeal, accessibility, and possibility to maintain access to the website in the future}

When asked to evaluate the website, more than two thirds of the students reported that it was very useful or useful; just over half said it was very interesting or interesting; and just under half referred to it as very or quite appealing. The percentage of students responding that the website was not useful, interesting or attractive was very low, always less than $5 \%$, while higher proportions reported being undecided. A significantly higher percentage of boys reported that the website was very appealing than did girls (Table 3). 
Table 3

Students' evaluation of usefulness, interest and attractiveness of the suckhoetre.vn website

\begin{tabular}{|c|c|c|c|c|c|c|c|}
\hline \multirow[t]{3}{*}{ Item } & \multirow{3}{*}{$\begin{array}{l}\text { Total } \\
\% \text { (n) }\end{array}$} & \multicolumn{3}{|l|}{ Sex } & \multicolumn{3}{|l|}{ School } \\
\hline & & Male & Female & $p^{a}$ & Specialized & Regular & $p^{a}$ \\
\hline & & $\%(n)$ & $\%(n)$ & & $\%(n)$ & $\%(n)$ & \\
\hline $\begin{array}{l}\text { Total sample } \\
\text { (n) }\end{array}$ & 634 & 313 & 321 & & 207 & 427 & \\
\hline Usefulness & & & & 0.554 & & & 0.112 \\
\hline Very much & $\begin{array}{l}15.8 \\
(100)\end{array}$ & 16.9 (53) & $14.6(47)$ & & $15.0(31)$ & $16.2(69)$ & \\
\hline Somewhat & $\begin{array}{l}54.6 \\
(346)\end{array}$ & $\begin{array}{l}54.6 \\
(171)\end{array}$ & $\begin{array}{l}54.5 \\
(175)\end{array}$ & & $60.4(125)$ & $\begin{array}{l}51.8 \\
(221)\end{array}$ & \\
\hline Undecided & $\begin{array}{l}29.0 \\
(184)\end{array}$ & $27.5(86)$ & $30.5(98)$ & & $24.6(51)$ & $\begin{array}{l}31.1 \\
(133)\end{array}$ & \\
\hline Not really & $0.6(4)$ & $1.0(3)$ & $0.3(1)$ & & $0(0.0)$ & $0.9(4)$ & \\
\hline Interest & & & & 0.740 & & & 0.771 \\
\hline Very much & $9.2(59)$ & $11.8(37)$ & $6.9(22)$ & & $10.1(21)$ & $8.9(38)$ & \\
\hline Somewhat & $\begin{array}{l}43.8 \\
(278)\end{array}$ & $\begin{array}{l}44.7 \\
(140)\end{array}$ & $\begin{array}{l}43.0 \\
(138)\end{array}$ & & $43.5(90)$ & $\begin{array}{l}44.0 \\
(188)\end{array}$ & \\
\hline Undecided & $\begin{array}{l}45.6 \\
(289)\end{array}$ & $\begin{array}{l}41.9 \\
(131)\end{array}$ & $\begin{array}{l}49.2 \\
(158)\end{array}$ & & $45.9(95)$ & $\begin{array}{l}45.4 \\
(194)\end{array}$ & \\
\hline Not really & $1.1(7)$ & $1.6(5)$ & $0.6(2)$ & & $0.5(1)$ & $1.4(6)$ & \\
\hline Not at all & $0.2(1)$ & $0.0(0)$ & $0.3(1)$ & & $0.0(0)$ & $0.2(1)$ & \\
\hline Appeal & & & & $0.024^{*}$ & & & 0.536 \\
\hline Very much & $6.6(42)$ & $9.3(29)$ & $4.0(13)$ & & $7.2(15)$ & $6.3(27)$ & \\
\hline Somewhat & $\begin{array}{l}40.4 \\
(256)\end{array}$ & $\begin{array}{l}41.2 \\
(129)\end{array}$ & $\begin{array}{l}39.6 \\
(127)\end{array}$ & & 41.1 (85) & $\begin{array}{l}40.0 \\
(171))\end{array}$ & \\
\hline Undecided & $\begin{array}{l}48.1 \\
(305)\end{array}$ & $\begin{array}{l}43.5 \\
(136)\end{array}$ & $\begin{array}{l}52.6 \\
(169)\end{array}$ & & 47.8 (99) & $\begin{array}{l}48.2 \\
(206))\end{array}$ & \\
\hline Not really & $3.9(25)$ & $4.8(15)$ & $3.1(10)$ & & $3.9(8)$ & $4.0(17)$ & \\
\hline Not at all & $0.9(6)$ & $1.3(4)$ & $0.6(2)$ & & $0.0(0)$ & $1.4(6)$ & \\
\hline
\end{tabular}

${ }^{a} \chi^{2}$ was used to compare differences in frequency of visiting the website according to sex and types of school.

* $p<0.05$ 
Regarding the content of the website, the health categories included health care, stress, emotions and feelings, depression, relationships, substance abuse and game addiction, nutrition, and reproductive health. The students reported that the topics of health care, stress, and nutrition were most appropriate to them and they also liked these the most. Other topics were of much less interest to most of the students. The least liked section was the one on drugs and game addictions.

The skills section contained tools for learning study skills, soft skills, career skills, handling situations, and protecting; these were considered "very suitable" for their own needs by $30.9 \%$ of the respondents. The health check-up section (providing ways to measure stress, depression, and self-esteem) was rated by only $18.3 \%$ as appropriate for them (Table 4 ).

Table 4

The most appropriate, liked and disliked items on the website

\begin{tabular}{|llll|}
\hline Item & $\begin{array}{l}\text { Most appropriate } \\
\%(\mathbf{n})\end{array}$ & $\begin{array}{l}\text { Most liked } \\
\%(\mathbf{n})\end{array}$ & $\begin{array}{l}\text { Most disliked } \\
\%(\mathbf{n})\end{array}$ \\
\hline Health & & & \\
\hline Health care & $57.6(365)$ & $42.3(272)$ & $2.8(18)$ \\
\hline Stress & $41.6(264)$ & $25.5(164)$ & $5.0(32)$ \\
\hline Nutrition & $33.3(211)$ & $22.6(143)$ & $3.0(19)$ \\
\hline Emotion and feeling & $19.6(124)$ & $11.2(71)$ & $6.0(38)$ \\
\hline Depression & $14.0(89)$ & $9.0(57)$ & $6.8(43)$ \\
\hline Reproductive health & $12.5(79)$ & $8.8(56)$ & $10.9(69)$ \\
\hline Relationship & $10.1(64)$ & $4.3(27)$ & $9.9(63)$ \\
\hline Stimulant drug and game addiction & $9.6(61)$ & $6.9(44)$ & $21.1(134)$ \\
\hline Skills & $30.9(196)$ & $21.5(136)$ & $4.3(27)$ \\
\hline Health check-up & $18.3(116)$ & $8.2(52)$ & $4.6(29)$ \\
\hline
\end{tabular}

A majority of the students thought that the website would appeal to their parents and friends. Furthermore, almost two-thirds felt that the website was very much or somewhat easy to access (Table 5). 
Table 5

Appeal and accessibility of the suckhoetre.vn website

\begin{tabular}{|c|c|c|c|c|c|c|c|}
\hline \multirow[t]{3}{*}{ Item } & \multirow{3}{*}{$\begin{array}{l}\text { Total } \\
\% \text { (n) }\end{array}$} & \multicolumn{3}{|l|}{ Sex } & \multicolumn{3}{|l|}{ School } \\
\hline & & Male & Female & $p^{a}$ & Specialized & Regular & $p^{a}$ \\
\hline & & $\%(n)$ & $\%(n)$ & & $\%(n)$ & $\%(n)$ & \\
\hline $\begin{array}{l}\text { Appeal to } \\
\text { parents }\end{array}$ & $\begin{array}{l}79.8 \\
(506)\end{array}$ & $\begin{array}{l}80.2 \\
(251)\end{array}$ & $\begin{array}{l}79.4 \\
(255)\end{array}$ & 0.446 & $81.2(168)$ & $\begin{array}{l}79.2 \\
(338)\end{array}$ & 0.316 \\
\hline $\begin{array}{l}\text { Appeal to } \\
\text { friends }\end{array}$ & $\begin{array}{l}72.9 \\
(462)\end{array}$ & $\begin{array}{l}73.8 \\
(231)\end{array}$ & $\begin{array}{l}72.0 \\
(231)\end{array}$ & 0.333 & 71.0 (147) & $\begin{array}{l}73.8 \\
(315)\end{array}$ & 0.261 \\
\hline Accessibility & & & & 0.920 & & & 0.206 \\
\hline Very much & $15.5(98)$ & $15.7(49)$ & $15.3(49)$ & & $14.0(29)$ & $16.2(69)$ & \\
\hline Somewhat & $\begin{array}{l}49.1 \\
(311)\end{array}$ & $\begin{array}{l}48.2 \\
(151)\end{array}$ & $\begin{array}{l}49.8 \\
(160)\end{array}$ & & $54.1(112)$ & $\begin{array}{l}46.6 \\
(199)\end{array}$ & \\
\hline Undecided & $\begin{array}{l}32.0 \\
(203)\end{array}$ & $\begin{array}{l}31.9 \\
(100)\end{array}$ & $\begin{array}{l}32.1 \\
(103)\end{array}$ & & $27.5(57)$ & $\begin{array}{l}34.2 \\
(146)\end{array}$ & \\
\hline Not really & $2.7(17)$ & $3.2(10)$ & $2.2(7)$ & & $3.9(8)$ & $2.1(9)$ & \\
\hline Not at all & $0.8(5)$ & $1.0(3)$ & $0.8(5)$ & & $0.5(1)$ & $0.9(4)$ & \\
\hline
\end{tabular}

${ }^{a} X^{2}$ was used to compare differences in appeal and accessibility levels of the website according to sex and types of school.

When the students were asked whether they would like the website to remain operational, nearly all of them $(96.5 \%)$ said yes. Most (89\%) planned to continue visiting the website in the future; most $(88.2 \%)$ also agreed they would introduce it to family members and friends, and $88.6 \%$ said they would introduce the website to families with members who have mental health problems.

In addition to the data from the questionnaires, we checked the data registered by the website one year after its introduction. The website registers the numbers of visits to different items, which revealed that the reproductive health item attracted the highest number of views $(850,713)$, followed by the emotion and feeling section (viewed 442,856 times), and the depression items (viewed 437,252 times). We do not have data on how many people made these visits, nor on who they are, whether they were the target populations in the secondary schools or youth in general or indeed parents or others interested in the health of young people. This data do, however, demonstrate that one year on, the website was still being consulted by many people.

\section{Discussion}

\section{Use of the mental health information website by secondary school students}


Although mental health problems are common among adolescents, barriers including social stigma prevent them from approaching the health services for information and possibly for assistance (Corrigan, 2004; Schomerus \& Angermeyer, 2008; Thornicroft, 2008). In the current context of high Internet use, we investigated whether information provided by a website designed to attract secondary school students would be a good way to provide them with information about this sensitive topic. After we introduced the website suckhoetre.vn to selected secondary schools in Cantho city, Vietnam, nearly all of the students visited the site at least once or twice a week, and most of them used the website just to read information, which suggests that this is a good approach to give students relatively easy access to information they need. These findings are in line with a report from Hue city, Vietnam in which both parents and students anticipated that the Internet would be a useful source for obtaining and sharing information for young people in Vietnam (Sobowale, Nguyen, Weiss, Van, \& Trung, 2016). Most of the youth in our study population had access to Internet at home and very often on a smartphone, which would provide the confidentiality they need. Previous studies on mental health of secondary school students in Cantho city had produced a recommendation to provide information through the Internet; the present study confirms that it can be effective as a source of information here as it has been elsewhere (Boydell et al., 2014; D. T. Nguyen, C. Dedding, T. T. Pham, \& J. Bunders, 2013; D. T. Nguyen, Dedding, Pham, Wright, et al., 2013).

Students in regular schools were significantly more likely to use the website to search for help than students in specilized schools. This may be explained either by different needs among the two types of students, or by different access to information apart from what is available on this website. According to the 2015-2016 school year annual report on academic performance of students from secondary schools in Cantho city by the Department of Education and Training, there were more students with high academic performance rankings in the specialized schools than in the regular schools (97\% versus less than 50\%) (Can Tho City Department of Education and Training, 2016). Previous research (D. T. Nguyen, Dedding, Pham, Wright, et al., 2013) found that students with lower academic performance were more likely to be at risk of depression, which might prompt them to seek help on the website.

One point arising from the results was that it was more common for boys than for girls to share information on the website $(p<0.05)$. This difference might be a result of differences in mental health issues and needs, or to a difference in willingness to share such information. It may be linked to the difference in personalities and self-esteem between boys and girls (Bailey, Zauszniewski, Heinzer, \& Hemstrom-Krainess, 2007) or in patterns of seeking help for psychological disorder (World Health Organization, 2019c). Future website information and programs on mental health should make efforts to integrate gender aspects into their content, to meet the needs of both boys and girls.

\section{Usefulness, relevance, interest, attractiveness, accessibility, and potential to maintain the suckhoetre.vn website}

Most of the respondents reported that the website was useful and interesting, confirming that it can be a good source of information for them. 
More boys than girls found the website was "very/extremely appealing" ( $9.3 \%$ vs $4.0 \%$ ), which suggests that gender needs to be considered in the design of the website to broaden its appeal. Previous studies have shown that males are more likely to give "extreme" answers in which they strongly agree or disagree (Sarsons \& Xu, 2015). In addition, as mentioned above, boys reported more often that they shared information that they found on the website. This could be a reason for the boys having found the website very appealing.

The topics of health care and psychological and mental health such as stress were considered very appropriate by most of the respondents. In addition, many students agreed that skills including soft skills, career skills, handling situations, and protecting skills were most useful for them. Following this, we suggest that in addition to having access to psychological and mental health information, it would be helpful for schools to provide training in these life skills that could help students to cope with daily stress (Sobowale et al., 2016). Therefore, it is important to take students' demands into account to provide the information related to health care, psychological and mental health, and skills.

Students also reported that the health check-up content helped them learn about depression, and selfesteem on the website was the most suitable and interesting to them. This result suggests that in addition to providing psychological and mental health information on the website, the health check section on the website can be useful to provide the first suggestion to students on whether they face mental health problems, and that could alert them to search for a diagnosis and early medical treatment.

\section{Limitations}

One limitation of this study relates to the sample, which was from senior secondary schools with students aged from 16 to 20 years, so a younger or older student population might have responded differently. This is, however, an age group with high levels of stress in making the transition to adulthood and a high need for good knowledge about mental health, as shown in previous publications (Center for Behavior Health Statistics and Quality, 2014; World Health Organization, 2019a). The study was undertaken in one large city in the south of Vietnam, which may mean that it is not representative for the whole country, although in the current context of media and the Internet, the youth in different locations share problems and concerns more often than in the past. Another limitation may be that the data was collected by self-reporting using standardized questionnaires. The young respondents' personality and identity development are still incomplete, which could result in fluctuating self-perceptions (Schraml, Perski, Grossi, \& Simonsson-Sarnecki, 2011) and thus unreliable reporting. The study did not include a way to cross-check on their self-report and their actual visits to the website. The data provide information on the students' use of the website, but did not attempt to find out about students' actual mental health problems or how the website might help them to seek help, which is, as described above, not readily available everywhere in the country. 
The majority of students believed that the website has the potential to appeal to parents and friends. In addition, many students said that it was easy for them to access. Many said that they hoped that the website would remain active and that they would return to it in the future. Many students said that they would introduce the website to their family, friends, and families of people with mental health problems. The results suggest that the website has high potential to expand its users to different groups in Vietnam. However, this is one of the first studies in Vietnam on using a website to provide information on psychology and mental health; much research remains to be done to establish the long-term usefuleness of such a website.

\section{Conclusion}

The results of this study suggest that a dedicated website can be a useful source of information on health and mental health for secondary school students in urban Vietnam, and may be an effective way to reach students in other parts of the country and the region. The interest shown by the students in the website reinforces previous recommendations that secondary schools in Vietnam should pay more attention to the mental health of their students. More research would be needed to evaluate the long-term usefulness of the website and whether it is appropriate for different school levels in Vietnam.

\section{Declarations}

\section{Ethical approval and consent to participate}

Ethical approval for the study was obtained from the Scientific and Technical Committee of the Can Tho University of Medicine and Pharmacy. The purpose of the study was introduced to the students before they were invited to join the study and asked to give their verbal consent. They were informed that they could refuse to answer any questions or stop completing the questionnaire at any time without giving any explanation, and that all the information would remain confidential. Students were not required to attach their name to the questionnaire. A small compensation of 20,000 VND (less than 1.00 USD) in cash was offered to the students after completing the questionnaire.

\section{Consent for publication}

Not applicable

\section{Availability of data and materials}

The datasets used and analysed during the current study are available from the corresponding author on reasonable request.

\section{Competing interests}

The authors declare that they have no competing interests. 


\section{Funding}

We acknowledge the financial support of the "Strengthening teaching and research capacity of preventive medicine staffs to meet the challenges of emerging infections and new environmental hazards to health" Project from the Dutch Organisation for International Cooperation Dutch Organisation for Internationalisation in Education (NUFFIC) and the Dutch government.

\section{Authors' contributions}

DTN, TTP, and JB jointly produced the idea and the study design. DTN, TTP and PW developed the survey tools. DTN and TTP coordinated the surveys and data collection in the field. Data analysis was done by DTN, TTP and PW. DTN was guided by JB and PW to produce the first draft and all authors contributed to the final version of the manuscript.

\section{Acknowledgement}

We thank the Coordinator Board for the project at Hanoi Medical University, Hanoi, Vietnam. We would especially like to thank the secondary school students who gave their time to participate in this study.

\section{References}

1. Bailey, M. K., Zauszniewski, J. A., Heinzer, M. M., \& Hemstrom-Krainess, A. M. (2007). Patterns of depressive symptoms in children. J Child Adolesc Psychiatr Nurs, 20(2), 86-95. doi:10.1111/j.17446171.2007.00090.x

2. Bệnh Lý Trầm Cảm. (2020). Trầm cảm ở trẻ em. Retrieved from https://benhlytramcam.vn/benh-lytram-cam/tram-cam-o-tre-em/

3. Bệnh Viện Tâm Thần Ban Ngày Mai Hương. (2020). Sức khỏe tâm thần trẻ em. Retrieved from https://www.maihuong.gov.vn/vi/suc-khoe-tam-than-tre-em.html

4. Boydell, K. M., Hodgins, M., Pignatiello, A., Teshima, J., Edwards, H., \& Willis, D. (2014). Using technology to deliver mental health services to children and youth: a scoping review. J Can Acad Child Adolesc Psychiatry, 23(2), 87-99.

5. Can Tho City Department of Education and Training. (2016). Annual school year 2015-2016 report on academic performace of students from secondary school in Cantho city. Retrieved from

6. Center for Behavior Health Statistics and Quality. (2014). The CBHSQ Report. Serious Mental Health Challenges among Older Adolescents and Young Adults. Retrieved from https://www.samhsa.gov/data/sites/default/files/sr173-mh-challenges-young-adults-2014/sr173mh-challenges-young-adults-2014/sr173-mh-challenges-young-adults-2014.htm

7. Cimigo. (2011). Internet Usage and Development in Vietnam. Retrieved from www.cimigo.com/en/download/research_report/348

8. Corrigan, P. (2004). How stigma interferes with mental health care. Am Psychol, 59(7), 614-625. doi:10.1037/0003-066X.59.7.614 
9. Duplaga, M., \& Dzida, D. (2013). The growth of e-health services focused on mental health. Zdrowie Publiczne i Zarządzanie, 11(4), 295-301.

10. EU-Vietnam Business Network. (2018). E-commerce industry in Vietnam report. Retrieved from https://evbn.org/e-commerce-industry-in-vietnam-report-edition-2018/

11. Mitchell, J., Vella-Brodrick, D., \& Klein, B. (2010). Positive psychology and the internet: A mental health opportunity. Electronic Journal of Applied Psychology, 6(2), 30-41.

12. Moock, J. (2014). Support from the Internet for individuals with mental disorders: advantages and disadvantages of e-mental health service delivery. Frontiers in Public Health, 2(65), doi: 10.3389/fpubh.2014.0006. doi:10.3389/fpubh.2014.0006

13. Nguyen, D. T. (2009). Child Maltreatment and mental health among first year students in Cantho University of Medicine and Pharmacy, Vietnam. (Thesis for Master of Public Health), Queensland University of Technology, Brisbane.

14. Nguyen, D. T., Dedding, C., Pham, T. T., \& Bunders, J. (2013). Perspectives of pupils, parents, and teachers on mental health problems among Vietnamese secondary school pupils. BMC Public Health, 13(1046). doi:https://doi.org/10.1186/1471-2458-13-1046

15. Nguyen, D. T., Dedding, C., Pham, T. T., \& Bunders, J. (2013). Perspectives of pupils, parents, and teachers on mental health problems among Vietnamese secondary school pupils. BMC Public Health, 13, 1046. doi:10.1186/1471-2458-13-1046

16. Nguyen, D. T., Dedding, C., Pham, T. T., Wright, P., \& Bunders, J. (2013). Depression, anxiety, and suicidal ideation among Vietnamese secondary school students and proposed solutions: a crosssectional study. BMC Public Health, 13, 1195. doi:10.1186/1471-2458-13-1195

17. Nguyen, D. T., Dedding, C., Pham, T. T., Wright, P., \& Bunders, J. (2013). Depression, anxiety, and suicidal ideation among Vietnamese secondary school students and proposed solutions: a crosssectional study. BMC Public Health, 13(1195). doi:https://doi.org/10.1186/1471-2458-13-1195

18. Nguyen, D. T., Dedding, C., Wright, P., Pham, T. T., \& Bunders, J. (2019). Low self-esteem and its association with anxiety, depression, and suicidal ideation in Vietnamese secondary school students: a cross-sectional study. Frontiers in Psychiatry Public Mental Health. doi:10.3389/fpsyt.2019.00698

19. Nguyen, D. T., Wright, E. P., Pham, T. T., \& Bunders, J. (2020). Role of School Health Officers in Mental Health Care for Secondary School Students in Can Tho City, Vietnam. School Mental Health. doi:https://doi.org/10.1007/s12310-020-09386-7

20. Nguyen, T. H. (2006). Child maltreatment in Vietnam: Prevalence and associated mental and physical health problems. Thesis for the Doctor Degree of Philosophy. Queensland University of Techonology. Brisbane.

21. Radloff, L. S. (1977). The CES-D Scale: A self-report depression scale for research in the general population. Applied Psychological Measurement, 1(3), 485-401.

22. Rosenberg, M. (1965). Society and the adolescent self-image. Princeton, NJ: Princeton University Press. 
23. Rosenberg, M. (1989). Society and the Adolescent Self-Image (Revised ed.). Middletown, CT: Wesleyan University Press.

24. Sanchez-Lopez Mdel, P., \& Dresch, V. (2008). The 12-Item General Health Questionnaire (GHQ-12): reliability, external validity and factor structure in the Spanish population. Psicothema, 20(4), 839843.

25. Sarsons, H., \& Xu, G. (2015). Confidence Men? Gender and Confidence: Evidence among Top Economists. Retrieved from https://scholar.harvard.edu/files/sarsons/files/confidence_final.pdf

26. Schomerus, G., \& Angermeyer, M. C. (2008). Stigma and its impact on help-seeking for mental disorders: what do we know? Epidemiol Psichiatr Soc, 17(1), 31-37. doi:10.1017/s1121189x00002669

27. Schraml, K., Perski, A., Grossi, G., \& Simonsson-Sarnecki, M. (2011). Stress symptoms among adolescents: The role of subjective psychosocial conditions, lifestyle, and self-esteem. Journal of Adolescence, 34, 987-996.

28. Sobowale, K., Nguyen, M., Weiss, B., Van, T. T. H., \& Trung, L. T. (2016). Acceptability of internet interventions for youth mental health in Vietnam. Glob Ment Health (Camb), 3, e22. doi:10.1017/gmh.2016.18

29. Thai, T. T., Kim, X. L., Nguyen, D. N., Dixon, J., Sun, J., \& Dunne, M. P. (2012). Validation of the Educational Stress Scale for Adolescents (ESSA) in Vietnam. Asia-Pacific Journal of Public Health, $X X(X)$.

30. The Nemours Foundation. (2020). KidsHealth fron Nemours. Retrieved from https://kidshealth.org/en/teens/your-mind/?WT.ac=t-nav-your-mind

31. Thornicroft, G. (2008). Stigma and discrimination limit access to mental health care. Epidemiol Psichiatr Soc, 17(1), 14-19. doi:10.1017/s1121189x00002621

32. Tran, B. P. (2007). Improving Knowledge of factors that influence the mental health of school children in Vietnam. Thesis of the Master of Public Health Degree. Queensland University of Technology. Brisbane.

33. UNICEF. (2018). The lack of mental health services in remote areas of Viet Nam leaves children and young people in need helpless. Retrieved from https://www.unicef.org/vietnam/press-releases/lackmental-health-services-remote-areas-viet-nam-leaves-children-and-young-people

34. van der Ham, L., Wright, P., Van, T. V., Doan, V. D., \& Broerse, J. E. (2011). Perceptions of mental health and help-seeking behavior in an urban community in Vietnam: an explorative study. Community Ment Health J, 47(5), 574-582. doi:10.1007/s10597-011-9393-x

35. World Health Organization. (2019a). Adolescent mental health. Retrieved from https://www.who.int/news-room/fact-sheets/detail/adolescent-mental-health

36. World Health Organization. (2019b). Child and adolescent mental health. Retrieved from https://www.who.int/mental_health/maternal-child/child_adolescent/en/

37. World Health Organization. (2019c). Gender disparities in mental health. Retrieved from https://www.who.int/mental_health/prevention/genderwomen/en/ 
38. Zulkefly, N. S., \& Baharudin, R. (2010). Using the 12-item General Health Questionnaire (GHQ-12) to Assess the Psychological Health of Malaysian College Students. Global Journal of Health Science, 1(2), 73-80. doi:10.5539/gjhs.v2n1p73

\section{Supplementary}

Supplementary file not available with this version 